\title{
INACTIVATION OF ESCHERICHIA COLI O157:H7 IN HAMBURGERS BY GAMMA IRRADIATION
}

\author{
Rodolfo R.O. Chirinos; Dirceu M. Vizeu; Maria Teresa Destro; \\ Bernadette D.G.M. Franco; Mariza Landgraf*
}

Departamento de Alimentos e Nutrição Experimental, Faculdade de Ciências Farmacêuticas, Universidade de São Paulo, São Paulo, SP, Brasil

Submitted: September 13, 2001; Returned to authors for corrections: January 28, 2002; Approved: February 25, 2002

\begin{abstract}
Escherichia coli $\mathrm{O} 157: \mathrm{H} 7$ causes bloody diarrhoea, haemorrhagic colitis and life-threatening complications like haemolytic uremic syndrome and thrombotic thrombocitopenic purpura. Among foods associated with outbreaks caused by this pathogen, hamburger is the most common one. The aim of this research was to determine the radiation dose to reduce the population of E. coli $\mathrm{O} 157: \mathrm{H} 7$ in hamburgers to non-detectable levels in order to render a safer product. Hamburgers, inoculated with Escherichia coli O157:H7, were exposed to gamma radiation $\left({ }^{60} \mathrm{Co}\right)$ treatment, with doses ranging from 0 to $0.7 \mathrm{kGy}$. The average temperature during the process was $5.6^{\circ} \mathrm{C}$. Non-inoculated hamburgers were submitted to sensory evaluation after being exposed to irradiation doses of $0.8 \mathrm{kGy}$ and $1.0 \mathrm{kGy}$. The $\mathrm{D}_{10}$ for the pathogen varied from $0.17 \mathrm{kGy}$ to O.27 kGy in hamburger. Considering the highest $\mathrm{D}_{10}$ value in hamburger, a dose of $1.08 \mathrm{kGy}$ would be sufficient to reduce E. coli $\mathrm{O} 157: \mathrm{H} 7$ contamination in $4 \log$ cycles, without affecting the sensory attributes of the product.
\end{abstract}

Key words: hamburger, patties, Escherichia coli O157:H7, food irradiation, gamma radiation

\section{INTRODUCTION}

Escherichia coli $\mathrm{O} 157: \mathrm{H} 7$ belongs to the enterohaemorrhagic class of Escherichia coli (EHEC). The disease caused by this bacterium is haemorrhagic colitis, and life-threatening complications like haemolytic uremic syndrome and thrombotic thrombocitopenic purpura may occur in haemorrhagic colitis patients (1). Various foods have already been associated with $E$. coli $\mathrm{O} 157: \mathrm{H} 7$ outbreaks, with hamburger being the most common. Processed food such as yoghurt, cheese and fermented sausage have also been involved in foodborne outbreaks caused by $E$. coli $\mathrm{O} 157: \mathrm{H} 7$ (16).

As cattle is the main reservoir of EHEC, with high rates of faecal carriage, the presence of this pathogen in raw meat is not surprising with contamination occurring during slaughter. Cooking meat thoroughly and pasteurizing milk are important measures of protection but are not sufficient by themselves.

Among food preservation methods, food irradiation is considered the most versatile treatment, nowadays. Microorganisms can be inactivated by impairment of important molecules or organelles, such as DNA and the cytoplasmic membrane (3). In 1980, the Joint Food and Agricultural Organization/International Atomic Energy Agency/World Health Organization committee on the Wholesomeness of Irradiated Food concluded that the irradiation of any food commodity up to an overall average dose of $10 \mathrm{kGy}$ presents no toxicological hazard and introduces no special nutritional or

\footnotetext{
* Corresponding author. Mailing address: Departamento de Alimentos e Nutrição Experimental, Faculdade de Ciências Farmacêuticas, Universidade de São Paulo, Av. Prof. Lineu Prestes, 580 - Bloco 14. 05508-900, São Paulo, SP, Brasil. Fax: (+5511) 3815-4410. Tel.: (+5511) 3091-2191. E-mail: landgraf@usp.br
} 
microbiological problems (22). Hence, gamma radiation became an important tool to be used by the food industry not only as a method of preserving food but also to improve food safety (12). Although the consumer resistance, these developments may lead towards more use of this technology in the future. In the United States, the US Food and Drug Administration approved irradiation of red meat in December 1997 (5) and, more recently, the United States Department of Agriculture (20) also approved its use for meat and poultry.

The aim of this research was to determine the gamma radiation dose to reduce the level of Escherichia coli O157:H7 in manufactured hamburger as well its effects on the sensory attributes.

\section{MATERIALS AND METHODS}

\section{Strain}

Escherichia coli O157:H7 EDL 933 (a hamburger isolate), obtained from the Departamento de Microbiologia, Imunologia e Parasitologia da Universidade Federal de São Paulo, Brazil, was used in this study.

The isolate was grown in $5 \mathrm{~mL}$ of nutrient broth (Difco, Detroit, MI) at $37^{\circ} \mathrm{C}$ for $24 \mathrm{~h}$. After this period, the culture was spread plated onto Sorbitol MacConkey agar (Oxoid, United Kingdom) and incubated at the same conditions. Ten typical colonies (sorbitol negative) were, then, transferred to $100 \mathrm{~mL}$ of nutrient broth and incubated at $37^{\circ} \mathrm{C}$ with agitation at $170 \mathrm{rpm}$ on a rotary shaker (Superhom) for $145 \mathrm{~min}$ to reach c.a. $10^{6} \mathrm{cfu} /$ $\mathrm{mL}$ as previously determined by a calibration growth curve.

\section{Irradiation treatment}

Cardboard packages containing 12 frozen hamburgers were acquired at the retail level at São Paulo city, Brazil. After the temperature reached $2^{\circ} \mathrm{C}$ in the center of each hamburger, as measured with a thermometer, individual hamburgers were asseptically transferred to styrofoam trays and $1 \mathrm{~mL}\left(10^{6} \mathrm{CFU} /\right.$ $\mathrm{mL}$ ) of $E$. coli $\mathrm{O} 157: \mathrm{H} 7$ was evenly distributed inside and on the surface of the hamburgers, using a syringe. After 15 minutes, each tray was wrapped with PVC (polyvinyl chloride) film and transported to the irradiation plant in insulated boxes. Noninoculated samples were used as controls. In each experiment, 21 trays containing one hamburger each were submitted to the irradiation treatment. The experiment was repeated 3 times.

Hamburgers were irradiated at EMBRARAD S.A., with a commercial-size ${ }^{60} \mathrm{Co}$ Gamma Beam JS7500 Irradiator (Nordion International Inc., Kanata, Ontario, Canada). The dose rate provided by the ${ }^{60} \mathrm{Co}$ source ranged from $3.5 \mathrm{kGy} / \mathrm{h}$ to $5.0 \mathrm{kGy} / \mathrm{h}$.

Sets of 3 trays were exposed to each of the following irradiation doses: $0.0 \mathrm{kGy} ; 0.1 \pm 3 \% \mathrm{kGy} ; 0.2 \pm 3 \% \mathrm{kGy} ; 0.3 \pm 3 \%$ $\mathrm{kGy} ; 0.4 \pm 3 \% \mathrm{kGy} ; 0.5 \pm 3 \% \mathrm{kGy}$ and $0.7 \pm 3 \% \mathrm{kGy}$. These doses were established using National Physical Laboratory (Middlesex, United Kingdom) dosimeters. After irradiation, hamburgers were maintained refrigerated until the beginning of microbiological analyses. Temperature of hamburgers was monitored before and after irradiation.

\section{Microbiological analyses}

The enumeration of E. coli $\mathrm{O} 157: \mathrm{H} 7$ in irradiated hamburgers was done using the Most Probable Number (MPN) method, with tryptic soy broth (Difco, Detroit, MI) as diluent and recovery medium (14). After $24 \mathrm{~h}$ incubation at $37^{\circ} \mathrm{C}$, tubes showing growth were streaked onto Sorbitol MacConkey agar (Oxoid, England). The colonies were confirmed as E. coli O157:H7 using proper biochemical tests and the E. coli antiserum O157 assay (Probac do Brasil).

Microbiological data were transformed into log units of the Most Probable Number/g ( $\left.\log _{10} \mathrm{MPN} / \mathrm{g}\right)$.

\section{Data on $\mathrm{D}_{10}$-value}

Survivor plots ( $\log _{10}$ No. of survivors vs. dose) were determined by regression analysis of the data. $D_{10}$ value was calculated as the reciprocal of the slope obtained in the regression analysis.

\section{Sensory characterization}

Non-inoculated samples were submitted to irradiation doses of $0.8,1.0$ and $1.2 \mathrm{kGy}$. Raw hamburgers were evaluated for color, odor, and appearance while cooked ones were evaluated for the same attributes plus taste. A six-member trained sensory panel evaluated samples using a descriptive analysis technique related to the qualitative aspect using unwrapped raw hamburger samples served in disposable dishes (10).

\section{RESULTS AND DISCUSSION}

$\mathrm{D}_{10}$ values for $E$. coli $\mathrm{O} 157: \mathrm{H} 7$ in hamburger ranged from $0.17 \mathrm{kGy}$ to $0.27 \mathrm{kGy}$ (Fig. 1). $\mathrm{D}_{10}$ values in solid food were higher than in liquid medium (data not shown). These results were already expected since compounds like proteins, carbohydrates, lipids, condiments and other components present in hamburgers will compete with the bacterium for interaction with free radicals produced during radiolysis (21). The broad variation in $\mathrm{D}_{10}$ values for hamburgers can be due to differences in composition of the hamburgers belonging to different brands. According to Monk et al. (11), some food preservatives also affect the growth or death of microorganisms when food is submitted to irradiation treatment. Therefore, the presence of these compounds could also have influenced the values obtained in this research.

The $\mathrm{D}_{10}$ values of $E$. coli $\mathrm{O} 157: \mathrm{H} 7$ reported here are very similar to those obtained by other authors. Patterson (13) reported $\mathrm{D}_{10}$ values of $0.27 \mathrm{kGy}$ and $0.39 \mathrm{kGy}$ for nonpathogenic $E$. coli in chicken meat packed in vacuum and in air, respectively. Thayer and Boyd (17) found a D value of 0.28 

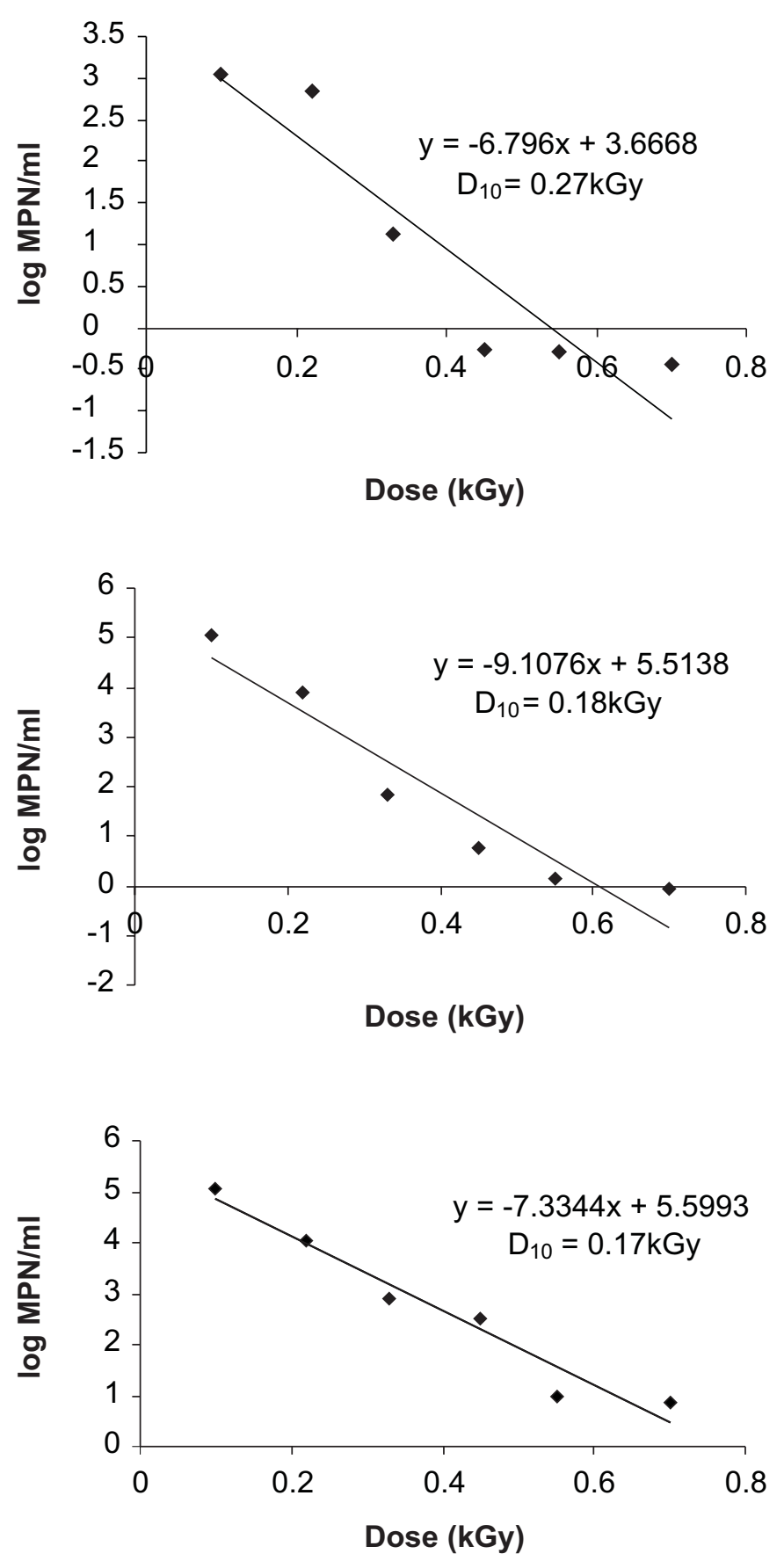

Figure 1. Reduction of Escherichia coli O157:H7 inoculated in hamburger exposed to gamma radiation.

kGy for E. coli O157:H7 inoculated in finely ground lean beef when irradiated in vacuum at $5^{\circ} \mathrm{C}$ and a value of $0.27 \mathrm{kGy}$ on either lean ground beef or mechanically deboned chicken meat. Dion et al. (4), studying the radioresistance of several strains of bacteria, among them, Yersinia enterocolitica, Vibrio parahaemolyticus, Salmonella typhimurium, Staphylococcus aureus, Listeria monocytogenes and Campylobacter jejuni, found $\mathrm{D}$ values varying from 0.03 to $0.06 \mathrm{kGy}$ for the less radioresistant, such as $E$. coli $\mathrm{O} 157: \mathrm{H} 7$. On the other hand, $S$. typhimurium and L. monocytogenes showed the highest resistance.

Our results do not agree with those of Dion et al. (4) and Clavero et al. (2) probably due to differences in the temperature during irradiation treatment, presence or absence of oxygen and substrate. Besides, different species or strains of the same species may require different doses to achieve the same degree of inactivation (3). Thayer and Boyd (18) concluded that the radioresistance of different serotypes of E. coli (2 nonpathogenic strains and 7 pathogenic ones) in red meat depended on the serotype and also on the temperature during irradiation $\left(5^{\circ} \mathrm{C}\right.$ and $\left.-5^{\circ} \mathrm{C}\right)$.

Another aspect to be considered is the methodology used in the recovery of cells after irradiation. The MPN methodology probably provided a better recovery of stressed cells than other methodologies where a recovery step is not included before the isolation step. Though culture media and incubation conditions for growth and estimation of pathogen populations following irradiation treatment are secondary factors, they must be considered. Stressed cells take two or more hours to recover after irradiation. Consequently, the medium and the incubation conditions can interfere in the recovery of the cells $(11,19)$.

The effect of irradiation on sensory quality of beef is of concern due to the formation of free radicals. Fresh meat has a high moisture content and the reaction of ionizing radiation with water leads to the formation of free radicals that react with molecules in the food, resulting in compounds with undesirable odor and taste (7).

Table 1 shows the results for the sensory evaluation. In our experiment, a dose of $1.2 \mathrm{kGy}$, capable of reducing the counts of E. coli $0157: \mathrm{H} 7$ in more than $4 \log$ cycles, imparted an unfavourable odor and taste to the hamburgers. Lefebvre et al. (9) observed the same phenomenon, but Rodriguez et al. (15) reported no changes in sensory attributes of beef treated with $2 \mathrm{kGy}$.

In relation to colour, the trained panel detected a slightly different colour in the hamburgers treated with $1.0 \mathrm{kGy}$ (Table 1). Similar results where found by Ginger et al. (6) and Huber et al. (8).

Therefore, considering the highest $\mathrm{D}_{10}$ value $(0.27 \mathrm{kGy})$, a dose of $1.08 \mathrm{kGy}$ would cause a $4 \log$ cycle reduction in the population of E. coli O157:H7 in hamburgers, without substantially changing their sensory attributes. Considering that hamburgers are usually ingested with mayonaise, tomato sauce and/or mustard sauce, the slight rancidity taste detected by the trained panel can be overcome. 
Table 1. Sensory attributes of hamburgers exposed to radiation doses of $0.0 \mathrm{kGy}, 0.8 \mathrm{kGy}$ and $1.0 \mathrm{kGy}$.

\begin{tabular}{|c|c|c|c|}
\hline $\begin{array}{l}\text { Sensory } \\
\text { attributes }\end{array}$ & $\begin{array}{l}\text { Standard } \\
(0.0 \mathrm{kGy})\end{array}$ & $\begin{array}{c}\text { Test } 1 \\
(0.8 \mathrm{kGy})\end{array}$ & $\begin{array}{c}\text { Test } 2 \\
(1.0 \mathrm{kGy})\end{array}$ \\
\hline Appearance & $\begin{array}{l}\text { Raw product: light, chestnut } \\
\text { brown patties with reddish dots. } \\
\text { fried product: oval-shaped, light } \\
\text { chestnut brown colour. } \\
\text { strong seasoning odour; light meat } \\
\text { odour. }\end{array}$ & $\begin{array}{l}\text { raw product: reddish colour patties with } \\
\text { chestnut brown dots. } \\
\text { fried product: oval-shaped, dark } \\
\text { chestnut brown colour. } \\
\text { strong seasoning odour; light meat } \\
\text { odour. }\end{array}$ & $\begin{array}{l}\text { raw product: dark, brown patties } \\
\text { with reddish dots. } \\
\text { fried product: oval-shaped, chestnut } \\
\text { brown colour; grease appearance. } \\
\text { strong meat and seasoning odour. }\end{array}$ \\
\hline
\end{tabular}

\section{RESUMO}

\section{Inativação de Escherichia coli 0157:H7 em hambúrgueres submetidos à irradiação gama}

Escherichia coli $\mathrm{O} 157: \mathrm{H} 7$ causa colite hemorrágica que pode evoluir para síndrome urêmica hemolítica e síndrome púrpura trombótica trombocitopênica. Entre os alimentos mais envolvidos nos surtos causados por essa bactéria destacamse os hambúrgueres de carne bovina. Esta pesquisa teve como objetivo determinar o valor $\mathrm{D}_{10}$ de E. coli $\mathrm{O} 157: \mathrm{H7}$ em hambúrgueres e sugerir uma dose que torne o alimento seguro em relação à essa bactéria e sem alterar suas características sensoriais. Amostras de hambúrgueres industrializados foram inoculados com Escherichia coli 0157:H7 e submetidos à radiação com raios gama $\left({ }^{60} \mathrm{Co}\right)$. A temperatura média durante o processo foi de $5,6^{\circ} \mathrm{C}$. O valor $\mathrm{D}_{10}$ no hambúrguer variou de 0,17 a $0,27 \mathrm{kGy}$. Considerando o maior valor $\mathrm{D}_{10}$ obtido, a dose de 1,08 kGy seria suficiente para reduzir a população de Escherichia coli $\mathrm{O} 157: \mathrm{H7}$ em 4 ciclos logarítmicos, sem que houvesse rejeição do produto pelo painel treinado de analistas.

Palavras-chaves: Escherichia coli O157:H7, hambúrguer, radiação ionizante, radiação gama, irradiação de alimentos

\section{REFERENCES}

1. Buchanan, R.L.; Doyle, M.P. Foodborne disease significance of Escherichia coli $\mathrm{O} 157: \mathrm{H} 7$ and other enterohemorrhagic E. coli. Food Technol., 51: 69-76, 1997.

2. Clavero, M.R.S.; Monk, J.D.; Beuchat, L.R.; Doyle, M.P. Inactivation of Escherichia coli O157:H7, Salmonella spp. and Campylobacter jejuni in raw ground beef by gamma-irradiation. Appl. Environm. Microbiol., 60: 2069-2075, 1994.

3. Diehl, J.F. Safety of irradiated foods. Marcel Dekker Inc., New York, 1995, 345p.

4. Dion, P.; Charbonneau, R.; Thibault, C. Effect of ionizing dose rate on the radioresistance of some food pathogenic bacteria. Can. J. Microbiol., 40: 369-374, 1994.

5. Food and Drug Administration. Irradiation in the production, processing and handling of food. Fed. Reg., 62: 64107-64121, 1997.
6. Ginger, I.D.; Lewis, U.J.; Schweigert, B.S. Changes associated with irradiating meat and meat extracts with gamma rays. J. Agric. Food Chem., 3: 156-159, 1955.

7. Groninger, H.S.; Tappel, A.L.; Knapp, F.W. Some chemical and organoleptic changes in gamma irradiated meats. Food Res., 21: 555-564, 1956.

8. Huber, W.; Brasch, A.; Waly, A. Effect of processing conditions on organoleptic changes in foodstuffs sterilized with high intensity eletrons. Food Technol., 7: 109-115, 1953.

9. Lefebvre, N.; Thibault, C.; Charbonneau, R.; Piette, J.-P.G. Improvement of shelf-life and wholesomeness of ground beef by irradiation. 2. Chemical analysis and sensory evaluation. Meat Sci., 36: 371-380, 1994.

10. Meilgaard, M.; Civille, G.V.; Carr, B.T. Sensory evaluation technics, $3^{\text {rd }}$ ed Boca Raton, 1999, 387p.

11. Monk, D.J.; Beuchat, L.R.; Doyle, M.P. Irradiation inactivation of foodborne microorganisms. J. Food Protect., 58: 197-208, 1994.

12. Mulder, R.W.A. Salmonella radicidation of poultry carcasses. Beekbergen: Spelderholt Institute for poultry research, Report 363. In: Mayer- Miebach, E. 1993. Review Article, Food Irradiation. A means of controlling pathogenic microorganisms in food. Food Sci. Technol., 26: 493-497, 1982.

13. Patterson, M. Sensitivity of bacteria to irradiation on poultry meat under various atmospheres. Lett. Appl. Microbiol., 7: 55-58, 1988.

14. Peeler, J.T.; Houghtby, G.A.; Rainosek, A.P. The Most Probable Number Technique. In: Vanderzant, C.; Splittstoesser, D.F. Compendium of Methods for the Microbiological Examination of Foods, Washington: APHA, 1992, p.105-120.

15. Rodriguez, H.R.; Last, J.A.; Mallo, R.A.; Marchevsky, N. Low-dose gamma irradiation and refrigeration to extend shelf-life of aerobically packed fresh beef round. J. Food Prot., 56: 505-509, 1993.

16. Smith, H.R. Vero cytotoxin-producing Escherichia coli O157: cause for concern. Soc. Gen. Microbiol. Quart., 42: 54-55, 1997.

17. Thayer, D.W.; Boyd, G. Elimination of Escherichia coli O157:H7 in meat by gamma irradiation. Appl. Environm. Microbiol., 59: 1030-1034, 1993.

18. Thayer, D.W.; Boyd, G. Radiation resistance of pathogenic coli serotypes. J. Food Protect., 58 (Suppl.), 33, 1995.

19. Thayer, D.W.; Boyd, G.; Fox Jr, J.B.; Lakritz, L.; Hampson, J.W. Variations in radiation sensitivity of foodborne pathogens associated with the suspending meat. J. Food Sci., 60: 63-67, 1995.

20. United States Department of Agriculture. Federal Register, v.65, n.10, p.2284-2285, Jan. 2000.

21. Urbain, W.M. Food irradiation. Academic Press, Orlando, 1986.

22. World Health Organization. Food irradiation. A technique for preserving and improving the safety of food. World Health Organization, p.23, 1988. 